\title{
Effect of plant density on yield and quality of different cultivars of sweet pepper
}

\author{
M.L. CHOUDHARY ${ }^{1}$ AND S.K. SINGH* \\ Department of Horticulture, Sam Higginbottom Institute of Agriculture Technology and Sciences, Naini, \\ ALLAHABAD (U.P.) INDIA
}

\begin{abstract}
An experiment was conducted on effect of plant density on yield and quality of different cultivars of sweet pepper at Department of Horticulture, Sam Higginbottom Institute of Agriculture, Technology and Sciences, Allahabad during the year 2009-2010. The experiment was laid out in $3 \times 5$ Factorial Randomized Block Design having 15 treatments and 3 replications. The treatment $\mathrm{T}_{8}$ (variety Lucky star-165 with spacing $60 \times 45 \mathrm{~cm}$ ) was found to be superior and statically significant over other treatment combinations, which recorded highest plant height $(34.50 \mathrm{~cm})$, plant spread $(60.66 \mathrm{~cm})$, number of leaves/plant $(137.00)$, number branches/plant $(9.57)$, time of flower bud initiation (52.41 day after transplanting), number of flower buds/plant (74.66), number of flowers/plant (51.20), number of fruits/plant (4.25), fruit length (4.91 cm), fruit yield (916.33g/plant), fruit yield (33.93t/ha), vitamin-C (130mg/100g) and T.S.S (17.26\%).
\end{abstract}

Key Words : Sweet pepper, Plant density, Yield, Quality

View Point Article : Choudhary, M.L. and Singh, S.K.(2015). Effect of plant density on yield and quality of different cultivars of sweet pepper. Internat. J. agric. Sci., 11 (1): 130-133.

Article History : Received : 28.10.2013; Revised : 23.11.2014; Accepted : 09.12.2014

\footnotetext{
* Author for correspondence

${ }^{1}$ Department of Vegetable Science, Dr. Yashwant Singh Parmar University of Horticulture and Forestry, Nauni, SOLAN (H.P.) INDIA
} 